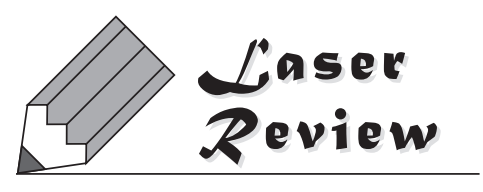

\title{
フェムト秒レーザーによる液相化学反応およびナノ材料創成
}

\author{
岡本 拓也, 中島 信昭, 八ッ橋 知幸 \\ 大阪市立大学大学院 理学研究科 (广558-8585 大阪府大阪市住吉区杉本3-3-138)
}

\section{Chemical Reactions and Nanomaterial Productions in Liquid Phase by Femtosecond Laser Pulses}

\author{
Takuya OKAMOTO, Nobuaki NAKASHIMA, and Tomoyuki YATSUHASHI \\ Osaka City University, 3-3-138 Sugimoto, Sumiyoshi, Osaka 558-8585
}

(Received November 29, 2016)

\begin{abstract}
We briefly review femtosecond laser induced chemical reactions and nanomaterial productions in a liquid phase. Focused intense femtosecond laser pulses create a high density of reactive species such as solvated electrons and cation radicals of the solvent. The solvated electrons efficiently reduce the metal ions followed by their nanoparticle formations. Multimetallic nanoparticles, which are expected to be utilized as electromagnetic materials and catalysts, are produced. In the cases of neat organic solvents, polyynes and carbon nanoparticles are formed. We also presented the production of heteroatom-doped carbon nanoparticles, which are candidates of oxygen reduction catalysts in fuel cells. By using aqueous organic solutions and/or water/organic bilayer solutions, hydrophilic carbon nanoparticles are formed by the successive oxidation of organic molecules by hydroxyl radicals. Nanoparticle synthesis by reactive species in the liquid phase might be an alternative means of widely used laser ablation in liquid.
\end{abstract}

Key Words: Laser ablation in liquid, Nanoparticles, Reduction, Oxidation, Solvated electrons

1.はじめに

レーザーを用いたナノ材料の作製は, 対象とする原料 の状態によりFig. 1 に示すa)気相, b) 固相(気一固界面), c) 液相，そしてd)液一固界面の4つに分類できる。気相か らの粒子生成(Fig. 1 (a)) は原料濃度に上限があるため収 量は少なく, 報告例はほとんどない. 最近, 時間および 空間的に整形したフェムト秒パルスをメタンに集光する ことで微少プラズマを発生させ, 球状粒子(85-500 nm)が 得られることが報告された1)。これに対し，いわゆるレー ザーアブレーション(Fig. 1(b)) については多くの報告が あり，レーザーPVDとして実用化されている2). 一方，有 機溶媒にレーザーを照射する (Fig. 1 (c)) と煤が生じる事 はよく知られていたものの，これまで取り立てて注目を 浴びることはなかった。しかし，生成した煤が炭素ナノ 粒子 ${ }^{3)}$ ，あるいはダイヤモンドライクカーボン (DLC) 類 ${ }^{4)}$ であることが分かり，その利用が期待されている。近年, 液体中に浸漬した固体試料にレーザーを照射し，アブ レーションにより微粒子を生成する液中レーザーアブ レーション(Fig. 1(d))が界面活性剤などの添加物が不要 なナノ粒子生成法として国内外で盛んに研究されてい る5)。当初はナノ秒レーザーが用いられたが, 現在では フェムト秒レーザーを用いた研究も多く報告されている。
液相高エネルギー反応はレーザー，真空紫外光，放射 線，放電，超音波あるいはマイクロ波などにより行われ てきた，最もよく研究されてきた対象は水である。水か ら生じた水和電子は共存する金属イオンを還元し, さら に凝集を経てナノ粒子を生成する。一方，水から生じる 活性酸素種の一つである水酸化ラジカルは共存する有機 分子を容易に酸化する.そのため水に溶け达んだ有害物 質の無害化処理などがさかんに研究されてきた. a)

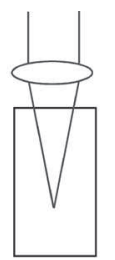

b)

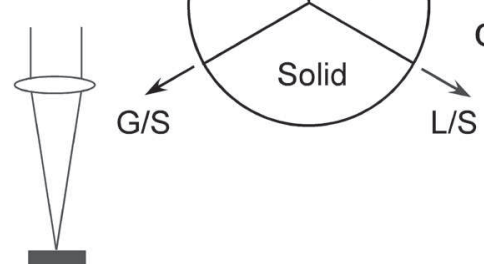

c)

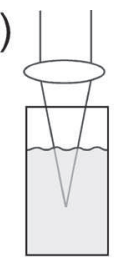

d)

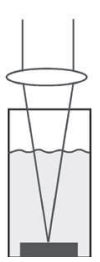

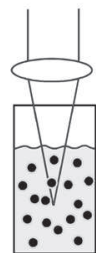

Fig. 1 Nanoparticle production in gas, solid, and liquid phases. 
液体中にフェムト秒レーザーを集光すると, 溶媒は容易 にイオン化して溶媒和電子とカチオンラジカルを生じる. その結果Fig. 2 に示すフイラメント状の光強度の高い部分 が形成され，同時に白色光(白色レーザー) が発生する. フィラメント中の電子密度は $10^{18} \mathrm{~cm}^{-3}\left(1.7 \times 10^{-3} \mathrm{~mol} \cdot \mathrm{dm}^{-3}\right)$ 程度と見積もられ，これは半導体や液晶製造のドライプ ロセスで用いられる高密度プラズマ源と同等である。ナ ノ秒レーザーでは $10^{9} \mathrm{~W} \cdot \mathrm{cm}^{-2}$ 程度で容易に溶媒の絶縁破 壊が生じるのに対し，フェムト秒レーザーでは $10^{13} \mathrm{~W} \cdot \mathrm{cm}^{-2}$ 程度まで強度を上げることができる.溶質の 濃度にもよるが, 近赤外フェムト秒レーザーを用いれば 溶質の反応よりも溶媒のイオン化が優先的に起きる.

本解説ではこれまで注目されることの少なかった純液 体そのものや溶液にフェムト秒レーザーを照射して化学 反応を誘起する, あるいはナノ粒子を生成する研究例に ついて紹介する。

\section{2. 有機化合物の液相化学反応と粒子生成}

フェムト秒レーザー照射によって有機溶媒の化学反応 を試みた例はごく少ない(Table 1)。へキサン ${ }^{6)}$ ，オクタ ン'), そしてアセトン ${ }^{8)}$ からのポリイン生成が報告されて いる，液中レーザーアブレーションによるポリイン生成と

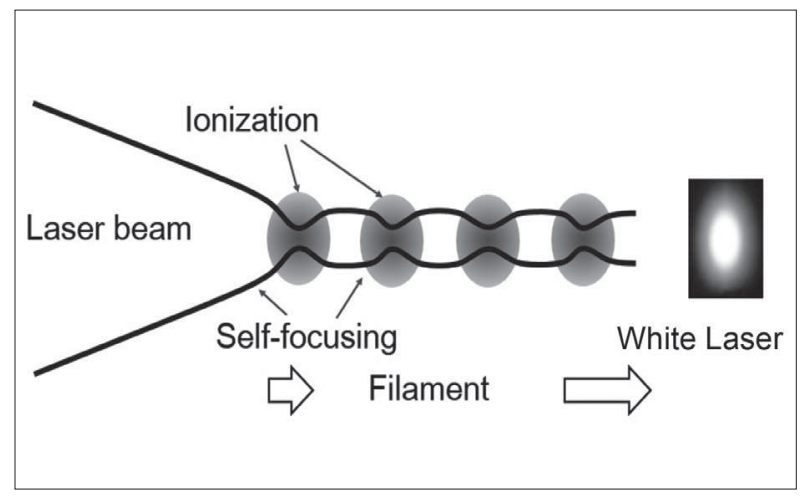

Fig. 2 A Schematic illustration of filament formation by NIR femtosecond laser pulse accompanied by white-light laser.
同様に, 一旦分子が断片化したのち炭素鎖の再構築によ りポリインが生成するとされている。しかし，ポリインは ごく一部生成するのみで主たる生成物ではなく，これが 一般的な反応とはいいがたい。ベンゼンからは多様な生 成物 ${ }^{9)}$, ナノ粒子 ${ }^{3,9)}$, そして $\mathrm{DLC}$ 類 $^{4)}$ の生成が報告されて いる。しかし, 単一の炭化水素系溶媒から生じた炭素粒 子は容易に凝結するため疎水性である。生物や医学など の分野で活用するためには官能基変換が容易な親水性炭 素粒子の方が望ましい筆者らはベンゼンと水の二層溶液

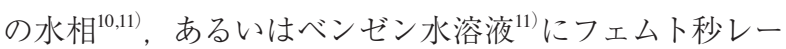
ザーを照射することで親水性の炭素ナノ粒子が生成でき ることを報告した。 また, $\mathrm{CH}_{2} \mathrm{Cl}_{2}$ 水溶液からは塩素を含 まない疎水性炭素粒子が ${ }^{22}, \mathrm{C}_{6} \mathrm{~F}_{6}$ からはフッ素を高密度に 含む親水性の炭素ナノ粒子が生成することを見出した $(\text { Fig. } 3)^{13)}$. 液体からのナノ粒子生成は液中レーザーアブ レーション ${ }^{14)}$ と同様に界面活性剂などの分散剤を用いず に水に分散する炭素ナノ粒子が生成できること, 原料と 生成物の分離が容易であること，レーザー照射条件の選 択の幅が大きいことが特徴として挙げられる。 その上, 溶液を用いる事で原料選択の範囲は極めて広くなる。し かし, 親水性炭素ナノ粒子が生成した際の溶液には数十 種類の分子が検出された，初期反応は推定できたものの, 最終的にナノ粒子に至る過程の追跡は困難であった ${ }^{11)}$.
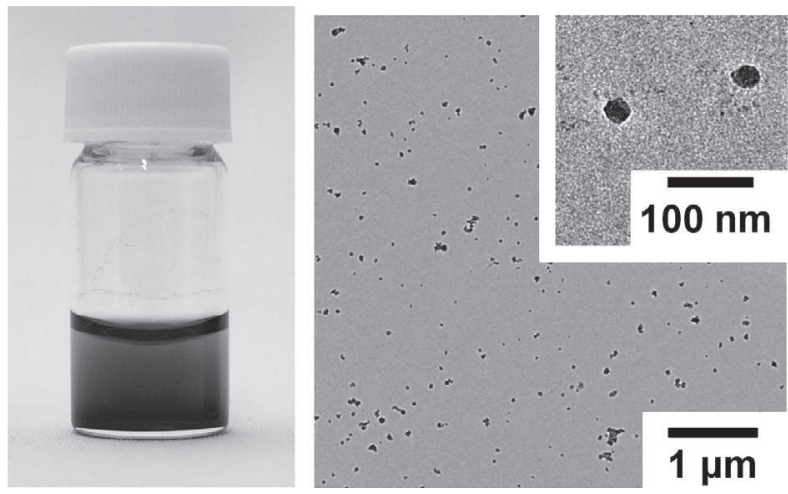

Fig. 3 The appearance and TEM images of water-dispersible highly-fluorinated $(\mathrm{F} / \mathrm{C}>0.4)$ carbon nanoparticles.

Table 1 Summary of Chemical Reactions and Nanomaterial Productions in Liquid Organic Molecules by Femtosecond Laser Pulses.

\begin{tabular}{ccccccc}
\hline Solute & Solvent & Wavelength $(\mathrm{nm})$ & Pulse width $(\mathrm{fs})$ & Energy $(\mathrm{mJ})$ & Products & Ref. \\
\hline none & $n-\mathrm{C}_{6} \mathrm{H}_{14}$ & 800 & 100 & $<0.94$ & polyyne & 6 \\
\hline none & $n-\mathrm{C}_{8} \mathrm{H}_{18}$ & 800 & 100 & 0.3 & polyyne & 7 \\
\hline none & acetone & 800 & 90 & 0.3 & polyyne & 8 \\
\hline none & $\mathrm{C}_{6} \mathrm{H}_{6}$ & 800 & 120 & 0.3 & polyyne, CNPs & 3 \\
\hline none & $\mathrm{C}_{6} \mathrm{H}_{6}$ & 780 & 100 & 5 & CNPs (DLC) & 4 \\
\hline none & $\mathrm{C}_{6} \mathrm{H}_{6}$ & 780 & 30 & $<2.2$ & PAHs, CNPs & 9 \\
\hline $\mathrm{C}_{6} \mathrm{H}_{6}$ & water & 800 & 40 & 0.4 & CNPs & 10,11 \\
\hline $\mathrm{CH}_{2} \mathrm{Cl}_{2}$ & water & 800 & 40 & 0.4 & CNPs & 12 \\
\hline $\mathrm{C}_{6} \mathrm{~F}_{6}$ & water & 800 & 40 & 0.3 & CNPs & 13 \\
\hline
\end{tabular}

a) CNPs: carbon nanoparticles, DLC: diamond-like carbon, PAHs: polycyclic aromatic hydrocarbons. 


\section{3. 金属イオンの反応と粒子生成}

フェムト秒レーザーを金属イオン溶液に照射すると金属ナ ノ粒子が生成する(Tables 2-3). 純金属 $\left(\mathrm{Ag}^{15)}, \mathrm{Au}^{16)}\right.$, $\left.\mathrm{Pt}^{17)}\right), 2$ 元系合金 $\left(\mathrm{Pd}-\mathrm{Pt}^{18)}, \mathrm{Au}-\mathrm{Pt}^{19,20)}, \mathrm{Ag}-\mathrm{Au}^{21,22)}\right.$, $\left.\mathrm{Fe}-\mathrm{Pt}^{20)}\right)$, そして3元系合金 $\left(\mathrm{Pd}-\mathrm{Pt}-\mathrm{Rh}^{23)}\right)$ など様々な組成 のナノ粒子が作製されている。特に異種金属ナノ粒子は 触媒, 磁性材料やプラズモニクスなどでの活用が期待さ れることから重要である。Fig. 4 には中村らが作製した Pd-Pt-Rhの3元系合金ナノ粒子について，原料溶液中の 元素比とナノ粒子の元素比の比較を示す ${ }^{23)}$. 原料として 用いた $\mathrm{Rh}^{\mathrm{III}} \mathrm{Cl}_{3}, \mathrm{Pd}^{\mathrm{II}} \mathrm{Cl}_{2}$, および $\mathrm{H}_{2} \mathrm{Pt}^{\mathrm{IV}} \mathrm{Cl}_{6}$ の仕达み比率が ほぼそのままナノ粒子の元素組成になり，3元系合金で あっても組成比の制御が可能であることがわかる，最 近，金属の混合溶液を一滴ずつ焼成することで合金ある いは相分離した異種金属ナノ粒子が生成できることが報 告された ${ }^{24)}$. しかし, 生産性という点では溶液へのレー ザー照射の方が格段に優れている.今後は状態(結晶, ア モルファス)の制御を含めた異種金属ナノ粒子の合成に 期待がもたれる。
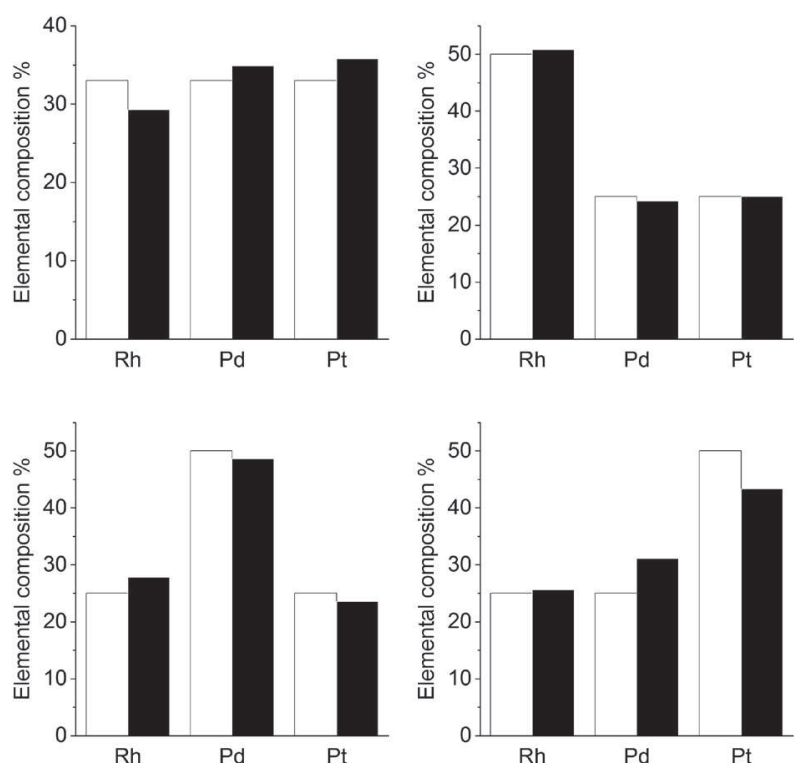

Fig. 4 Elemental compositions of reactant solutions $(\square)$ and nanoparticles ( $\boldsymbol{\|}$ ) produced by femtosecond laser pulses. Data were taken from Table 6 in Ref. 23.
フェムト秒レーザーを用いたとしても，溶液に数mJ 程度のエネルギーを集光した場合は溶媒の絶縁破壊が起 こる。また，溶質の多光子吸収も考慮する必要があ る.中島らは，数百 $\mu \mathrm{J}$ 程度のパルスを用いてランタノイ ド類 $\left(\mathrm{Eu}^{25)}, \mathrm{Sm}^{26)}\right)$ の光還元反応 $($ Table 4)を行った際に 白色光と共に激しい泡の発生を報告している。一方，溶 媒の絶縁破壞しきい值よりも小さい $\mu \mathrm{J}$ 程度のエネルギー のパルスでも金属の還元 $\left(\mathrm{Yb}^{27)}\right)$ が起こること (Table 4), $\mathrm{Ag}^{27)}, \mathrm{Au}^{28)}$ ，そして $\mathrm{Pd}^{28)}$ 溶液からナノ粒子が生成する ことを報告している(Table 2)。これらの実験では溶質で ある金属錯体の濃度は小さく，多光子吸収により錯体は 直接原子化されない.その一方で，溶媒である純水は $\mu \mathrm{J}$ 程度のエネルギーであっても，その約 $15 \%$ を多光子吸収 する。これらの結果は金属の還元とナノ粒子の生成が水 から放出された電子によるものであることを明確に示し ているといえる。

\section{4. 有機金属化合物の反応と粒子生成}

無機塩溶液を原料とした場合はTables 2-3 に示すよう に金属ナノ粒子が生成する。これらの反応では粒子生成 に溶媒の関与は認められない。液中レーザーアブレー ションにおいても，溶媒はこれまで単なる冷媒として認 識されてきた。しかし，例えばInPを原料とした液中 レーザーアブレーションではInP粒子に加えてInのみの 粒子や溶媒と $\mathrm{P}$ の応によるリン酸類の生成が報告され ている ${ }^{29)}$ 。また，エタノール中の $\mathrm{Sr}_{2} \mathrm{MgSi}_{2} \mathrm{O}_{7}$ の液中レー ザーアブレーションにおいては $\mathrm{Sr}(\mathrm{HCOO}){ }_{2}$ が生成物の うち $76 \%$ を占めること，その生成量がレーザー強度に依 存することが報告されている30)。これらの結果は溶媒を ナノ粒子生成過程に積極的に関与させることが可能であ ることを意味している。一方，有機金属化合物を原料に 用いた場合には配位子の脱離・分解が起こると予想され るため，配位子由来の軽元素が粒子に含まれるかどうか に興味が持たれる。しかし，フェムト秒レーザー照射を 用いた試みはごく少なく，フェロセンのベンゼン溶液か ら炭素殼 (4-25 $\mu \mathrm{m})$ や有機金属粒子 ${ }^{31)}$ が生成するという 報告のみである。これに対し，可視あるいは紫外ナノ秒 レーザー照射による有機金属粒子の生成の報告は少なか らずあるが32，この場合は光反応が主であって溶媒由来 の活性種の寄与はほとんどないと考えられる。

Table 2 Summary of Various Nanomaterial Productions in Metal Complex Solutions by Femtosecond Laser Pulses.

\begin{tabular}{cccccccc}
\hline Solute & Solvent & Additives & $\begin{array}{c}\text { Wavelength } \\
(\mathrm{nm})\end{array}$ & $\begin{array}{c}\text { Pulse width } \\
(\mathrm{fs})\end{array}$ & Energy & Products $^{\text {b) }}$ & Ref. \\
\hline $\mathrm{Ag}^{\mathrm{I} N \mathrm{NO}_{3}}$ & water & none/PVP & 800 & 100 & $6 \mathrm{~mJ}$ & $\mathrm{Ag} \mathrm{NPs}$ & 15 \\
\hline $\mathrm{HAu}^{\mathrm{III}} \mathrm{Cl}_{4}$ & water & none/PVP & 780 & 100 & $6 \mathrm{~mJ}$ & $\mathrm{Au} \mathrm{NPs}$ & 16 \\
\hline $\mathrm{H}_{2} \mathrm{Pt}^{\mathrm{IV}} \mathrm{Cl}_{6}$ & water & none/PVP & 780 & 100 & $5 \mathrm{~mJ}$ & $\mathrm{Pt} \mathrm{NPs}$ & 17 \\
\hline $\mathrm{Ag}^{\mathrm{I}} \mathrm{ClO}_{4}$ & water, 2-propanol & PANa & 800 & 100 & $2-10 \mu \mathrm{J}$ & $\mathrm{Ag}_{\mathrm{n}}^{+}$ & 27 \\
\hline $\mathrm{Ag}^{\mathrm{I}} \mathrm{ClO}_{4}$ & water, 2-propanol & SDS & 800 & 100 & $<5 \mu \mathrm{J}$ & $\mathrm{Ag} \mathrm{NPs}$ & 28 \\
\hline $\mathrm{HAu}^{\mathrm{III}} \mathrm{Cl}_{4}$ & water & SDS & 800 & 100 & $<5 \mu \mathrm{J}$ & $\mathrm{Au} \mathrm{NPs}$ & 28 \\
\hline $\mathrm{Pd}^{\mathrm{II}} \mathrm{Cl}_{2}$ & $\mathrm{HCl}$, water, ethanol & none & 800 & 100 & $<6 \mu \mathrm{J}$ & $\mathrm{Pd} \mathrm{NPs}$ & 28 \\
\hline $\mathrm{Fe}^{\mathrm{II}} \mathrm{Cp}_{2}$ & benzene & none & 800 & 100 & $300 \mu \mathrm{J}$ & $\mathrm{FeC} \mathrm{shells}$ & 31 \\
\hline
\end{tabular}

a) PANa: sodium polyacrylate, SDS: sodium dodecyl sulfate, PVP: polyvinylpyrrolidone, b) NPs: nanoparticles. 
Table 3 Summary of Various Nanomaterial Productions in Mixed Metal Complex Solutions by Femtosecond Laser Pulses (100 fs).

\begin{tabular}{ccccccc}
\hline Solute & Solvent & Additives & $\begin{array}{c}\text { Wavelength } \\
(\mathrm{nm})\end{array}$ & Energy (mJ) & Products & Ref. \\
\hline $\mathrm{Pd}^{\mathrm{II}} \mathrm{Cl}_{2}, \mathrm{H}_{2} \mathrm{PI}^{\mathrm{IV}} \mathrm{Cl}_{6}$ & water & none & 800 & 5 & Pd-Pt NPs & 18 \\
\hline $\mathrm{HAu}^{\mathrm{III}} \mathrm{Cl}_{4}, \mathrm{H}_{2} \mathrm{Pt}^{\mathrm{IV}} \mathrm{Cl}_{6}$ & water & none & 800 & 5 & Au-Pt NPs & 19 \\
\hline $\mathrm{HAu}^{\mathrm{III}} \mathrm{Cl}_{4}, \mathrm{H}_{2} \mathrm{Pt}^{\mathrm{IV}} \mathrm{Cl}_{6}$ & water & PVP & 780 & 3 & Au-Pt NPs & 20 \\
\hline $\mathrm{H}_{2} \mathrm{Pt}^{\mathrm{IV}} \mathrm{Cl}_{6}, \mathrm{Fe}^{\mathrm{III}} \mathrm{Cl}_{3}$ & water & PVP & 780 & 3 & Fe-Pt NPs & 20 \\
\hline $\mathrm{HAu}^{\mathrm{III}} \mathrm{Cl}_{4}, \mathrm{Ag}^{\mathrm{I}} \mathrm{NO}_{3}$ & water & PVP & 800 & 6 & Ag-Au NPs & 21 \\
\hline $\mathrm{HAu}^{\mathrm{III}} \mathrm{Cl}_{4}, \mathrm{Ag}^{\mathrm{I}} \mathrm{NO}_{3}$ & hexane & DDA & 800 & 5.7 & Ag-Au NPs & 22 \\
\hline $\mathrm{Rh}^{\mathrm{III}} \mathrm{Cl}_{3}, \mathrm{Pd}^{\mathrm{II}} \mathrm{Cl}_{2}, \mathrm{H}_{2} \mathrm{Pt}^{\mathrm{IV}} \mathrm{Cl}_{6}$ & water & TCD, PVP & 800 & 5.3 & Pd-Pt-Rh NPs & 23 \\
\hline
\end{tabular}

a) PVP: polyvinylpyrrolidone, TCD: trisodium citrate dihydrate, DDA: dodecylamine, b) NPs: nanoparticles.

Table 4 Summary of Various Chemical Reactions in Metal Complex Solutions by Femtosecond Laser Pulses.

\begin{tabular}{ccccccc}
\hline Solute & Solvent & Wavelength $(\mathrm{nm})$ & Pulse width $(\mathrm{fs})$ & Energy $(\mu \mathrm{J})$ & Products & Ref. \\
\hline $\mathrm{Eu}^{\text {III }} \mathrm{Cl}_{3}$ & methanol $^{\text {a) }}$ & 800 & 45 & $<307$ & $\mathrm{Eu}^{2+}$ & 25 \\
\hline $\mathrm{Sm}^{\mathrm{III}} \mathrm{Cl}_{3}$ & methanol $^{\text {a) }}$ & 800 & 43 & $5 \times 10^{2}$ & $\mathrm{Sm}^{2+}$ & 26 \\
\hline $\mathrm{Yb}^{\mathrm{III}} \mathrm{Cl}_{3}$ & methanol $^{\text {a) }}$ & 800 & 43 & $2-26$ & $\mathrm{Yb}^{2+}$ & 27 \\
\hline $\mathrm{Yb}^{\mathrm{III}} \mathrm{Cl}_{3}$ & methanol $^{\text {a) }}$ & 970 & 130 & $3-40$ & $\mathrm{Yb}^{2+}$ & 27 \\
\hline $\mathrm{Yb}^{\mathrm{III}} \mathrm{Cl}_{3}$ & methanol $^{\text {a) }}$ & 1930 & - & $4-10$ & $\mathrm{Yb}^{2+}$ & 27 \\
\hline $\mathrm{K}_{3} \mathrm{Fe}^{\text {III }}\left(\mathrm{C}_{2} \mathrm{O}_{4}\right)_{3}$ & water $^{\text {b) }}$ & 800 & 100 & $0.2-12$ & $\mathrm{Fe}^{2+\mathrm{d})}$ & 27 \\
\hline $\mathrm{K}_{3} \mathrm{Fe}^{\mathrm{IIII}}\left(\mathrm{C}_{2} \mathrm{O}_{4}\right)_{3}$ & $\mathrm{D}_{2} \mathrm{O}^{\mathrm{c})}$ & 1190 & 100 & $1.3-12$ & $\mathrm{Fe}^{2+}$ & 27 \\
\hline
\end{tabular}

a) degassed, b) with $\mathrm{H}_{2} \mathrm{SO}_{4}$, c) with $\mathrm{D}_{2} \mathrm{SO}_{4}$, d) two-photon reduction of $\mathrm{Fe}^{3+}$.

\section{5. まとめ}

純有機溶媒へのフェムト秒レーザー照射の試みは数例 にすぎないが，通常の手法では合成が困難なポリインな どが生成することが報告されている。, 一方, 有機物の水 溶液からはへテロ原子を高密度に含む親水性炭素ナノ粒 子が生成するなど，元素組成を制御した炭素粒子の生成 が期待できる。また，金属イオンの混合溶液にフェムト 秒レーザーを照射することで組成を制御した合金ナノ粒 子が合成できる.それぞれ燃料電池の酸素還元触媒や磁 性材料などへの活用が期待できる材料になりうる。 今後 は対象の拡大, 反応機構の解明, そして液中レーザーア ブレーションとの併用などによって粒径, 形態, 表面の 性質, 元素組成, そして状態(結晶, アモルファス等)を 制御したナノ粒子生成法の開発を期待したい.

\section{参考文献}

1) S. L. Shumlas, K. M. Tibbetts, J. H. Odhner, D. A. Romanov, R. J. Levis, and D. R. Strongin: Mater. Chem. Phys. 156 (2015) 47.

2) D. Bäuerle: Laser Processing and Chemistry (Springer-Verlag, Berlin, 2000).

3) M. J. Wesolowski, S. Kuzmin, B. Moores, B. Wales, R. Karimi, A. A. Zaidi, Z. Leonenko, J. H. Sanderson, and W. W. Duley: Carbon 49 (2011) 625.

4) T. Nakamura, Y. Mochidzuki, and S. Sato: OSA Technical Digest on Conference on Lasers and Electro-Optics/Quantum Electronics and Laser Science Conference and Photonic Applications Systems Technologies, Baltimore, May, 2007, JThD89.

5) F. Mafuné, J. Kohno, Y. Takeda, T. Kondow, and H. Sawabe: J.
Phys. Chem. B 104 (2000) 8333.

6) Y. Sato, T. Kodama, H. Shiromaru, J. H. Sanderson, T. Fujino, Y. Wada, T. Wakabayashi, and Y. Achiba: Carbon 48 (2010) 1673.

7) A. A. Zaidi, A. Hu, M. J. Wesolowski, X. Fu, J. H. Sanderson, Y. Zhou, and W. W. Duley: Carbon 48 (2010) 2517.

8) A. Hu, J. Sanderson, A. A. Zaidi, C. Wang, T. Zhang, Y. Zhou, and W. W. Duley: Carbon 46 (2008) 1823.

9) S. L. Kuzmin, M. J. Wesolowski, and W. W. Duley: Appl. Opt. 52 (2013) 8169 .

10) T. Yatsuhashi, N. Uchida, and K. Nishikawa: Chem. Lett. 41 (2012) 722 .

11) T. Hamaguchi, T. Okamoto, K. Mitamura, K. Matsukawa, and T. Yatsuhashi: Bull. Chem. Soc. Jpn. 88 (2015) 251.

12）宮坂 枝理奈, 瀆口智行, 八ッ橋 知幸: 電気学会論文誌 $\mathrm{C}$ 135 (2015) 1075.

13) T. Okamoto, K. Mitamura, T. Hamaguchi, K. Matsukawa, and T. Yatsuhashi: ChemPhysChem doi: 10.1002/cphc.201600602.

14） M.-Y. Choi, D.-S. Kim, D. S. Hong, J. H. Kim, and Y.-T. Kim: Chem. Lett. 40 (2011) 768.

15) T. Nakamura, H. Magara, Y. Herbani, and S. Sato: Appl. Phys. A 104 (2011) 1021

16) T. Nakamura, Y. Mochidzuki, and S. Sato: J. Mater. Res. 23 (2008) 968.

17) T. Nakamura, K. Takasaki, A. Ito, and S. Sato: Appl. Surf. Sci. 255 (2009) 9630.

18) T. Nakamura and S. Sato: J. Nanosci. Nanotechnol. 15 (2015) 426.

19) T. Nakamura, Y. Herbani, and S. Sato: J. Nanopart. Res. 14 (2012) 785.

20) J. L. H. Chau, C.-Y. Chen, and C.-C. Yang: Arab. J. Chem. doi: 10.1016/j.arabjc.2013.04.014.

21) Y. Herbani, T. Nakamura, and S. Sato: J. Nanomater. 2100 (2010) 154210.

22) Y. Herbani, T. Nakamura, and S. Sato: J. Phys. Chem. C 115 (2011) 21592.

23) M. S. I. Sanker, T. Nakamura, and S. Sato: J. Nanopart. Res. 17 (2015) 259.

24) P.-C. Chen, X. Liu, J. L. Hedrick, Z. Xie, S. Wang, Q.-Y. Lin, M. C. 
Hersam, V. P. Dravid, and C. A. Mirkin: Science 352 (2016) 1565 .

25) D. Nishida, M. Kusaba, T. Yatsuhashi, and N. Nakashima: Chem. Phys. Lett. 465 (2008) 238.

26) D. Nishida, E. Yamade, M. Kusaba, T. Yatsuhashi, and N. Nakashima: J. Phys. Chem. A 114 (2010) 5648.

27) N. Nakashima, K. Yamanaka, A. Itoh, and T. Yatsuhashi: Chin. J. Phys. 52 (2014), 504.

28) N. Nakashima, K. Yamanaka, M. Saeki, H. Ohba, S. Taniguchi, and T. Yatsuhashi: J. Photochem. Photobiol. A 319 (2016) 70.
29）加賀谷俊介, 江原祥隆, 北本仁孝, 舟窪浩, 原正彦, 山崎陽太郎, 小田原修, 和田裕之：レーザー研究 40 (2012) 117

30) F. Yoshimura, K. Nakamura, F. Wakai, M. Hara, M. Yoshimoto, O. Odawara, and H. Wada: Appl. Surf. Sci. 257 (2011) 2170.

31) M. J. Wesolowski, S. Kuzmin, B. Wales, J. H. Sanderson, and W. W. Duley: J. Mater. Sci. 48 (2013) 6212.

32) Y. Hayasaki, T. Fukuda, T. Hasumura, and T. Maekawa: Adv. Nat. Sci.: Nanosci. Nanotechnol. 3 (2012) 035010. 